\title{
Compress Algorithm
}

National Cancer Institute

\section{Source}

National Cancer Institute. Compress Algorithm. NCI Thesaurus. Code C80222.

A UNIX compression program based on the LZC compression method. 